\title{
CULTURAL ADJUSTMENTS IN TRANSLATION OF ENGLISH TO INDONESIAN IN NATIONAL GEOGRAPHIC
}

\author{
Yoharwan Dwi Sudarto, Suhartono, and Mintowati \\ Fakultas Pascasarjana, Universitas Negeri Surabaya, Indonesia \\ Jalan Lidah Wetan, Surabaya, Indonesia \\ Corresponding Author: yoharwansudarto16070835044@mhs.unesa.ac.id
}

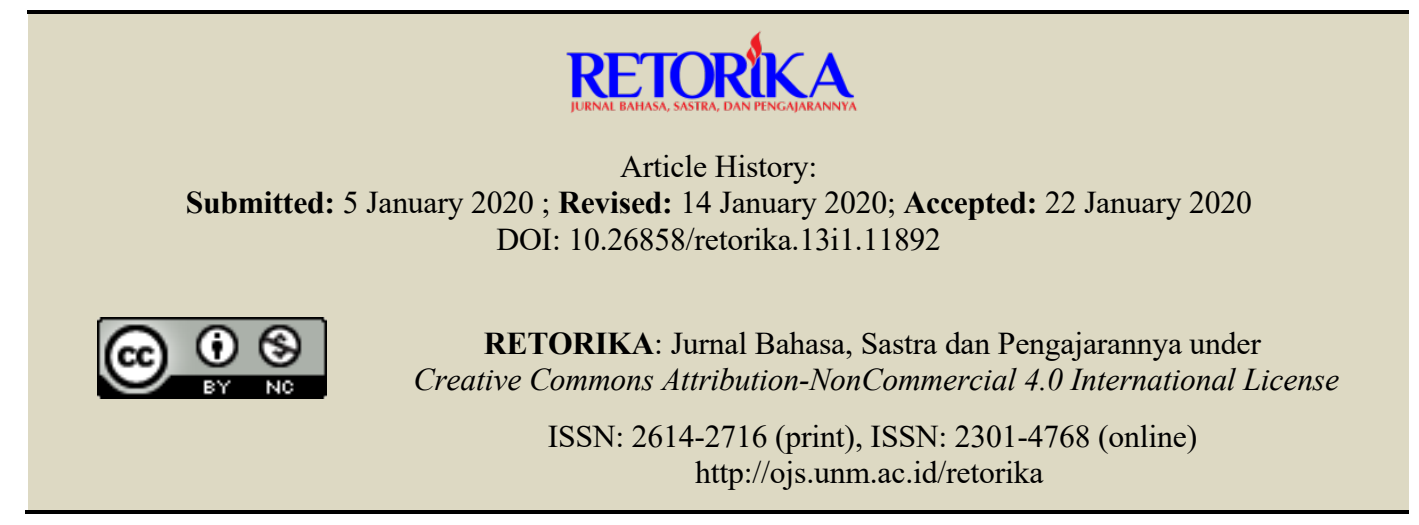

\begin{abstract}
This study describes the technique in translation which is used in the TV show National Geographic. The technique is from Molina and Albir. This research is aiming to discover the culture adaptation, addition and reduction, literal translation, linguistic adaptation in the subtitle from source language to target language. This research is started by choosing the show, transcripting the English, and rewriting the subtitle on the screen. After that, the data is analyzed from the culture adaptation point of view in translating English into Indonesian. The result of this research showed that there is culture adaptation in translating English as source language into Indonesian as target language. First point is the cultural adaptation which adapts with the habit of communicating in target language. This adaptation needs comprehension of the habit of communication in both language. Second, it is addition and reduction which make the result of translation more informative, short, and logical. Next thing is the literal translation which translates the source language literally. Then the linguistic adaptation which adapts the grammar of source language to target language. The data received had been researched to be analyzed in the translation technique.
\end{abstract}

Keywords: Translation, culture adaptation, source language, target language.

Learning in the current era is not only done in the classroom. With an internet connection connected to a laptop, students can learn with video learning or knowledge that available on the internet. The rapid development of technology in the present allows people to be able to access information quickly. Watching videos is one alternative in the delivery of material because it is equipped with pictures relating to the topics disscussed. There are many benefits of watching videos that contain knowledge content. First, the delivery of material becomes clearer because video is audio visual. This helps students who have a visual tendency in the learning process. Further-more, videos can be watched by anyone, anytime, and anywhere so the teaching and learning process becomes more practical.

It is a fact that English is an international language that has been used in almost all parts of the world so it is the duty of the international 
community to study it. English is often used so that communication between countries runs well. The communication can be oral or written. In communication and information on the internet, English is used as a second language in addition to the official language of their country. The aim is to convey existing thoughts to people who do not understand the language of the country they are using.

In the current era of globalization, people not only access the information they need but also they get access to provide information to the world community through the internet network. Some social media like Facebook, Twitter or Instagram have millions of users from all over the world. These sites are used to provide information or obtain information. One of the media used is video. They can upload videos made on Youtube so that the world community can watch it. Because video can be accessed by the entire world community, the language of choice in the delivery is English.

English competence is important for the world community because that way people can catch messages from English-language videos watched on the internet. However, constraints occur if the user has low competency in English. Videos containing information and knowledge will not be understood by people whose English competence is low. Of course this will be a big obstacle in obtaining information. One solution to deal with this is to provide a translation in the video. The translated text is written by a translator based on the results of the translation process of a show. The translated text is displayed in each explanation so that the audience can catch the message contained in the show.

One example of an English-language program that has been translated into Indonesian is National Geographic. National Geographic is a paid television channel that contains shows that contain knowledge about science, social science, and motivation. This event is well known in the world and witnessed by people from various countries in the world. On this channel, viewers can watch shows related to visual displays that help viewers better understand the topics discussed. The program was not dubbed, but was given a translated text.

Translation is the activity of transferring the source language (SL) to the target language (TL). Translation is the replacement of textual material in the source language with the target language. In the process, the translator always tries to get elements of the target language that are almost the same as the source language in order to give the same message in the target text. Translating English into Indonesian requires an interpreter who understands the intricacies of the two languages. This is very important to avoid misunderstanding in the audience. Both English and Indonesian have different structures, cultures and usages. In compiling translations from English into Indonesian, a translator must compile translated texts by adjusting various things because each language has its own grammatical and cultural structure that applies in the area. One example is figurative in a language, for example simile. Gibbs in Fadaee (2011: 22) states that similes are expressions that funda-mentally require open references to the source, target set, and an explicit construction that connects them.

Language differences are not only found in the meaning but also in the use of the language. The use of language in each language is very dependent on the local culture. For example in English, the word 'you' means kamu in Indonesian. In English formal and informal situations, the word 'you' is used. However, kamu is the word used for informal conversations in Indonesian. If the situation is formal, then the word used is anda. From these examples, there are cultural differences between the two languages.

This study attempts to examine the translation techniques used by translators in translating the contents of National Geographic shows. Translator technique is investigated because with this technique translators can convey the message contained in the source language. If the results of the translation cannot make it easier for the reader to capture the message in the source language, then the reader will get a different interpretation. The result of a good translation is able to enable the reader to grasp the intention to be achieved in the source language.

In a scientific publication article, research on translation was also conducted by Fitria in 2015. The article discussed the translation of texts from English into Indonesian in the film Stand by Me. The translation technique used also uses eighteen Molina and Albir techniques. The study explained how the translated text of the film was translated using Molina and Albir's translation techniques. 
The results of the study are the eleven types of translation techniques used in translating the film. namely (1) Adaptation, 112 data or $10.28 \%$, (2) Amplification, 80 data or $7.35 \%$, (3) borrowing, 93 data or $8.54 \%$, (4) calque, 30 data or $2.7 \%$, (5) compensation, 4 data or $0.37 \%$, (6) discursive creation, 2 data or $0.18 \%$, (7) established equivalence, 296 data or $27.18 \%$, (8) literal translation, 276 data or $25.34 \%$, (9) modulation, 48 data or $4.41 \%$, (10) reduction, 235 data or $21.58 \%$, and (11) transposition, 199 data or $18.27 \%$. From that research also seen the most dominant technique, namely Established Equivalence. There are around 297 data (or 27.27\%).

In this article, the writer uses the translation techniques described by Molina and Albir. In addition to uniformity, the techniques put forward by Molina and Albir have been through complex research by comparing and referring to the existing translation techniques from previous translators. The following translation techniques are based on cultural adjustment.

First, adaptation. This technique is a translation that changes the cultural elements that are specific in source language (SL) with the cultural elements that are in target language (TL). This technique can be used if elements or cultural elements are referenced. The following are examples of translation techniques that use adaptation.

\section{SL: His leg feels like a stone}

TL: Kakinya seperti terpaku

The phrase like a stone is translated into seperti terpaku. However, in Indonesian the phrase does not want to mention that his feet are like stones. What is meant is that his feet cannot be moved. In the Indonesian equivalent, the word terpaku or transfix becomes the right word to interpret the word because it has the same message.

This technique requires knowledge of meaning in foreign language terms and also requires the ability to find similar equivalents in TL. Therefore, a translator is required to be able to master the terminology of the foreign language he masters.

Second, borrowing. Borrowing techniques are translation techniques that use words or expressions from the source language in the target language. Borrowing can be in the form of pure borrowing, ie borrowing without making any changes, such as the word zig-zag, or in the form of natural borrowing (naturalized borrowing), where the word from SL is adjusted to the TL spelling, as the word musik originates from the word music.

Third, compensation. This translation technique is translation that replaces the position of the information element or the stylistic effect in SL in other parts of TL because it cannot be realized in the same section in TL.

SL: A burning desire to share The Secret with the world consumed me.

TL: Hasrat yang menyala-nyala untuk membagikan Rahasia kepada dunia membakar diri saya. (Hendrastuti, 2012: 189)

In the words consumed me, the translator interpreted membakar diri saya. This translation uses compensation that seeks to interpret new words in accordance with the concepts and the effects of their statistics. The word consumed me can be translated with other words that have the same concept and stylistic effect according to the translator's choice. As for examples of other translations that can be chosen in interpreting the word consumed me, namely:

(1) menghabisiku dan

(2) menelanku.

Fouth, discursive creation. This translation technique is a translation technique that uses a temporary equivalent that is far from its original condition. This technique often appears in the translation of film titles, books and novels. The criterion of this translation technique is if there are words, phrases or sentences that are unique to the source language then they are translated into the target language far from the original meaning. The following are examples of translation techniques that use discursive creation techniques.

\section{SL: Husband for A Year (Rebecca Winters) \\ TL: Suami sementara}

From the example above, the translation for a year is temporary. The results of the translation are very far from the original context.

Fifth, established equivalence. Common matching techniques are techniques for translating terms in the source language with terms that are already quite common in the target language. 
The terms in the source language are usually based on dictionaries or expressions used daily. The following are examples of translation techniques that use conventional matching techniques.

\section{SL: Sincerely yours}

TL: Hormat Kami

\section{METHOD}

This research uses a qualitative approach. This type of research is descriptive research. It aims to describe the translation in detail. In line with the opinion of Mahsun (2005), in research that is descriptive or synchronous there are three stages of research implementation, namely the provision of data, data analysis, and the presentation/formulation of the results of analysis which are stages that must be passed.

The source of the data in this study is the National Geographic programs broadcast in Indonesia which are translated into Indonesian. The program of study is a program that discusses general knowledge and has been translated by the translation into Indonesian. Researchers have specialized shows that will be studied, namely about the story of God. The title of the show taken was "The Story of God". There are several episodes that air on the topic.

The program on National Geographic has a duration of approximately one hour. The data taken is narrative text from narrators who speak English and translated text from Indonesian screen. With this data, researchers hope to get complete data to be examined and studied. In addition, the selected program is a program that is broadcast between 2016-2018. The restriction of the year was taken for the present data source.

The research data used is the source language narrative namely English and Indonesian translation from English at the National Geographic program. The Indonesian translation of this program is shown when the narrator presents the topic. The data is collected based on each episode. This data is used as a source of data by researchers to study.

Based on the methods that have been described, there are several techniques that will be used, namely listening and recording techniques. Mahsun (2005: 217) explains the rever to technique is the provision of data by listening to the use of language. As a basic technique, it has an advanced technique, which is the technique of engaging and engaging in proficiency.

The method of listening is a method carried out by listening which is paralleled by the observation method. In line with what was stated by Sudaryanto (1993: 133) the technique used in this study was a competent, free listening technique. In listening to the object of research, researchers do the following things:

(1) Open the youtube site and search for $\mathrm{Na}$ tioonal Geographic programs;

(2) Download programs that meet the criteria

(3) Watch programs by looking at Indonesian translations;

(4) Transcribe spoken English into written language;

(5) Rerecord the results of the English translation text.

The instrument used in this study was the human instrument. The researcher acts as a human instrument because the researcher himself will go into the field to get the data. Researchers will act as observers and analysts. The researcher will use the results of written English transcription and Indonesian translation texts to be researched and analyzed.

In conducting research, researchers will use tools such as laptops and cellphones. Laptops are used by researchers to access data sources on the internet. Then, the cellphone will be used to record the narration in the National Geographic show.

The method used in this research is descriptive qualitative analysis method. This research was conducted with qualitative data analysis because the empirical data obtained was qualitative data in the form of tangible collections of words and not a series of numbers.

Data analysis technique in analyzing the data of this study is a qualitative analysis technique. In this study, researchers will link elements that are lingual and elements that are in language. In line with Mahsun (2005: 117), the analytical method used for intralingual and extralingual equivalents because this study will compare two different languages, namely the source language and the target language.

The instrument used in data analysis in this study was the human instrument. Researchers will use their ability to analyze the data to be obtained. Then, the researcher will write down 
the results of his analysis in the form of an explanation. The explanation is in the form of sentences that are presented in paragraph form.

\section{FINDINGS AND DISCUSSION}

\section{Findings}

This research found some cultural adjustments in the translation of English into Indonesian. This adjustment is in accordance with the translation techniques of Molina \& Albir. Here are the results of his research.

\section{Adaptation}

This study found a translation that uses adaptation techniques. Here are the data found and the explanation.

\section{Data 1 \\ SL: I stepped over the stage into the light and the words and action flowed ef- fortlessly. \\ TL: Aku naik ke atas panggung, berdiri di bawah sinar lampu. Lalu kata-kata mengalir dengan mudah.}

In the sentence I stepped upon the stage the translator means that Aku naik ke atas panggung. The translation is adjusted because stepped upon should mean naik ke atas. Translators chose to use it because in Indonesian it is more general. In translating a language, translation must be made close to its original meaning. The choice of words must also be logical in accordance with the target language.

\section{Data 2 \\ SL: Every year in Thailand, people who believe they have been chosen by Tao- ist God perform superhuman rituals. \\ TL: Setiap tahun di Thailand orang-orang yang percaya telah dipilih Dewa Tao menampilkan ritual manusia super.}

In the second data above, there is the word Taoist God whose translated text is the Dewa Tao. The translator uses the word Dewa to translate the word God because the word Dewa is used for religions that believe in many gods. Taoism is one of religions that believes in many gods. Therefore, the word Dewa is very appropriate to use in this translation.

\section{Data 3}

SL: This American village situated about 50 miles south of the Dunbar cave, was the center of the religious life for the Cherokee ancestors.

TL: Desa asli Amerika ini terletak di 80 $\mathrm{km}$ selatan gua Dunbar. Pusat keturunan Cherokee yang religious.

In data 3 there is the word 50 miles. The unit used in distance measurement is the mile or miles in Indonesian. Mile is a unit of measurement in distance calculation. However, mile units are ra-rely used in Indonesian language habits. The unit of measurement used in Indonesian is kilometer. In its translation, the translator converts miles into units of kilometers. 1 mile means $1,609 \mathrm{~km}$. The-refore, in the data of $3 \mathrm{SL}$ 50 miles are converted to units of $\mathrm{km}$ to $80 \mathrm{~km}$. 2.5 miles is converted to $4 \mathrm{~km}$.

\section{Borrowing}

This research found translation using lending techniques. The following data and explanation.

Data 4

SL: This is where it all began for me. My Acting career.

TL: Di sinilah tempat semua berawal bagiku, Karir aktingku.

If we look at my acting career translated Karir aktingku. The word akting is absorbed from English, acting. Likewise with the word karir which is an absorption word that comes from the word career already. What changed was the pattern of the word.

Data 5

SL: And a guru who is no longer human. It cannot be corrupted.

TL: Dan seorang guru yang bukan manusia lagi. Dia tidak bisa dirusak.

In data 5 there is the word guru whose translation is also guru. The teacher in English means religious teacher. The translation is also exactly the same as the source language. This borrowing is direct because the words that are translated directly absorbed without changing the words. This data shows direct borrowing from the source language, namely English, into the target language, Indonesian. 


\section{Compensation}

This research found translation using compensation techniques. The following data and explanation.

Data 6

SL: So were you in fact praying and worshipping in North Korea.

TL: Jadi, apa kau benar bersembahyang dan beribadah di Korea Utara?

In the above data, the words praying and worshiping are translated as bersembahyang dan beribadah. Generally the words praying and worshipping have the meaning of berdoa and meтuja. But in this context, the translator uses the word bersembahyang and beribadah to explain what this person is doing in North Korea. $\mathrm{He}$ was there acting as a missionary so bersembahyang and beribadah were translated as general acts.

Data 7

SL: Can you talk about it?

TL: Can you tell?

In translating the phrase can you talk about $i t$ ? the translator looks at the previous context in which a missionary who had a bad experience in North Korea. The word can be used to give a stylistic effect that is in accordance with the conditions of the conversation. In general, the word can be translated with the word bisa. To describe the stylistic elements of translation, they translated with the word sanggup.

\section{Common Equivalent (Established Equivalence)}

Common translation translation techniques are also found in this translation. Here are the data.

Data 8

SL: Welcome to the oldest shrine in Phuket.

TL: Selamat datang di salah satu kuil tertua di Phuket.

The word welcome is commonly translated as selamat datang. Another example is also found in the following example.

Data 9

SL: Yes, it's started. Oh my goodness, that's just happened.

\section{TL: Ya sudah dimulai. Astaga. Baru ter- jadi.}

In the phrase Oh my goodness, the translator translates with the word Astaga. If we translate it literally, then the translation will be oh kebaikanku. However, this was not done by the translator. That's because Oh my goodness is an expression in English to express awe or surprise. In Indonesian, the expression to express awe is usually the astaga, astagfirullah, ya ampun.

In the process of translating in SL to TL on National Geographic shows, translators must adjust the cultural factors of the two languages studied. Translation data that have been studied show that there is an adjustment of the cultural factors of SL, in this case English into TL, namely Indonesian. The cultural adjustment is in the form of replacement of idioms, proverbs, measurement systems, choice of words, everyday expressions, borrowing of foreign languages. From the research conducted, it can be seen that the results of the research show that in the translation of SL to TL, many adjustments are adjusted to the Indonesian language conditions as TL. This is because in compiling a good and easy-to-understand translation, you must follow the language method.

\section{Discussion}

The results of the data show that SL and TL have different culture and language habits. This can be seen from the example of using the system of units of weight and length. In SL, which is English, the unit of foot and pound becomes a unit that is often used in linguistics. But in TL, in this case Indonesian, the more commonly used units in daily language are meters and kilograms. This adjustment can be seen from the results of the translated text. Not only that, but translations are not always word for word. Sometimes translation just replaces the same idea. This can be seen from the translation of proverbs. The translation of proverbs from SL uses proverbs from TL that have the same ideas.

Judging from the results of research on the translation of the National Geographic TV program, the translator is really careful in translating English into Indonesian. The sentences on the show are translated in clear and easy to understand language. Molina \& Albir's translation techniques are also seen in the translation pro- 
cess. Although it involves two different languages, two different cultures and two different people, the meaning or message that is transferred from the source language into the target language has the same idea.

Among the translation techniques based on cultural adjustment there is one technique from Molina \& Albir that is not found in the translation process, namely the variation technique. The translation technique is a translation technique that replaces linguistic or paralinguistic elements that affect linguistic variations, for example changes in textual tone, style, geographical dialect, and social dialect. This technique is not used in translating National Geographic shows because the language used is formal language. The translation technique is more used in informal situations so that the technique is less suitable to be used in translating the show.

When viewed from the results of the translation, it seems the language used tends to be formal. National Geographic shows use a lot of narration in the delivery of content. The choice of words used in the translation uses the choice of words arranged so that the reader can understand the contents of the show being displayed.

The results of this study are in line with research which in his study entitled Translation of Children's Novels from English to Indonesian. In his research, he examined the results of the translation which also adjusts to the cultural conditions of the TL. There are some research results that are not translated because they contain elements that are not good for children. The word was omitted in order to maintain a bad influence on them. In addition, there are also trans-

\section{REFERENCES}

Fadaee, E. (2011). Translation techniques of figures of speech: A case study of George Orwell's "1984 and animal farm". Journal of English and Literature, 2(8), 174-181. ISSN 2141-2626

Hendrastuti, R. (2012). Kajian terjemahan metafora yang menunjukkan sikap dalam buku motivasi the secret. Tesis. Surakarta: UNS. lations that experience changes in meaning that adjust to TL.

To improve the quality of translation results, researchers who will study the translation problem must understand the correct translation techniques to be used. The quality of the translation results is determined by three aspects, namely accuracy, acceptability and readability. Of course, the best results are translations with a high degree of accuracy, acceptance and readability. However, with various considerations in practice it is sometimes difficult to produce perfect translations. Often translators are faced with the choice to put more emphasis on one aspect and sacrifice a few other aspects.

\section{CONCLUSION}

From the results of the above research it can be concluded that the translation of English into Indonesian on National Geographic TV shows requires cultural adjustment. This can be seen from the choice of words used in translating the narration of the program. Translation techniques based on cultural adjustments are used in the process of translating English texts on National Geographic shows. The translation techniques use a cultural approach to translating SL. Cultural adjustments are needed for translation because SL and TL have different linguistic cultures. This can be seen from the adjustment of language, idioms, word choices, unit systems, daily expressions. The translation on National Geographic shows adjusting English to Indonesian as TL by taking into account linguistic cultural elements.

Mahsun. (2005). Metode penelitian bahasa: Tahapan strategi, metode, dan tekniknya. Jakarta: PT Raja Grafindo Persada.

Sudaryanto. 1993. Metode dan aneka tehnik analisis bahasa: Pengantar penelitian wahana kebudayaan secara linguistik. Yogyakarta: Duta Wacana University Press. 